\title{
Investigation of the Dose-Dependency of Citicoline Effects on Nerve Regeneration and Functional Recovery in a Rat Model of Sciatic Nerve Injury
}

\author{
Suçan Siyatik Sinir Hasaru Modelinde Sinir Rejenerasyonu ve Fonksiyonel \\ İyileşmesinde Sitikolinin Doza Bağıml Etkisinin İncelenmesi
}

Tolga KAPLAN ${ }^{1}$, Ilker Mustafa KAFA ${ }^{2}$, Mehmet CANSEV ${ }^{3}$, Ahmet BEKAR ${ }^{1}$, Necdet KARLI ${ }^{4}$, Mevlut Ozgur TASKAPILIOGLU ${ }^{1}$, Fulya KANAR ${ }^{3}$

1 Uludag University, Faculty of Medicine, Department of Neurosurgery, Bursa, Turkey

${ }^{2}$ Uludag University, Faculty of Medicine, Department of Anatomy, Bursa, Turkey

${ }^{3}$ Uludag University, Faculty of Medicine, Department of Pharmacology, Bursa, Turkey

${ }^{4}$ Uludag University, Faculty of Medicine, Department of Neurology, Bursa, Turkey

Corresponding Author: Ahmet BEKAR / E-mail: abekar@uludag.edu.tr

\begin{abstract}
AIM: The aim of this study was to investigate the dose dependence of citicoline's previously-reported effects on recovery of peripheral nerve injury.

MATERIAL and METHODS: Right sciatic nerves of sixty adult female Wistar Albino rats were incised and primary anastomosis was performed. Rats were then divided into four groups: Control group received $2 \mathrm{ml}$ of saline intraperitoneally, while rats in C-300, C-600 and C-900 groups received $300 \mu \mathrm{mol} / \mathrm{kg}, 600 \mu \mathrm{mol} / \mathrm{kg}$ and $900 \mu \mathrm{mol} / \mathrm{kg}$ citicoline dissolved in $2 \mathrm{ml}$ saline, respectively. Rats were tested for sciatic functional index (SFI) on the 4th, 8th and 12th weeks and electrophysiological recordings were obtained on the 12th week. Rats were then sacrificed to investigate nerve adhesions and perform histomorphological examinations.

RESULTS: Our results showed that rats in C-600 and C-900 groups had significantly lesser neural adhesion and greater SFland electrophysiological score than those in the Control and $\mathrm{C}-300$ groups $(\mathrm{p}<0.05)$. Mean density and total number of functionally myelinated axons were significantly increased in C-900 group, while perineural scar tissue formation was reduced in all citicoline-treated groups.

CONCLUSION: We conclude that citicoline exhibits dose-dependent effects on axonal regeneration and recovery without scar formation in a rat model of peripheral nerve incision and primary anastomosis.
\end{abstract}

KEYWORDS: Peripheral nerve, Citicoline, Regeneration

öz

AMAÇ: Bu çalışmanın amacı, periferik sinir hasarının iyileşmesinde sitikolinin daha önceden bildirilen doz bağımlı etkisinin araştırılmasıdır. YÖNTEM ve GEREÇLER: Altmış erişkin dişi Wistar Albino sıçanın sağ siyatik sinirleri kesilerek primer anostomoz uygulandı. Sıçanlar dört gruba ayrıldı: Kontrol grubunda $2 \mathrm{ml}$ salin intraperitoneal olarak uygulandı. C-300, C-600 ve C-900 gruplarında sırası ile $300 \mu \mathrm{mol} / \mathrm{kg}, 600 \mu \mathrm{mol} / \mathrm{kg}$ ve $900 \mu \mathrm{mol} / \mathrm{kg}, 2 \mathrm{ml}$ salin içinde çözünmüşs sitikolin uygulandı. Sıçanlar 4., 8., 12. haftalarda siyatik fonksiyon indeksi ile değerlendirildiler ve 12. haftada elektrofizyolojik ölçümler yapıldı. Sıçanlar sinir yapışıklı̆̆ını araştırmak ve histomorfolojik araştırmalar için feda edildiler.

BULGULAR: Araştırmamızın sonuçlarına göre, C-600 ve C-900 gruplarındaki sıçanlarda C-300 grubundaki sıçanlara göre belirgin olarak az nöral yapışıklık, daha iyi siyatik fonksiyon indeksi ve elektrofizyolojik sonuçlar elde edilmiştir $(p<0,05)$. C-900 grubunda ortalama yoğunluk ve fonksiyonel myelinli aksonların total sayısında belirgin artış saptanmıştır. Sitikolinle tedavi edilen tüm gruplarda perinöral skar dokusu azalmıştır.

SONUÇ: Sitikolin, aksonal rejenerasyonda ve sıçan periferik sinir kesilme ve primer anostomoz modelinde skar dokusu oluşmadan iyileşmede doza bağımlı olarak etki gösterir.

ANAHTAR SÖZCÜKLER: Periferik sinir, Sitikolin, Rejenerasyon 


\section{INTRODUCTION}

CDP-choline (cytidine-5'-diphosphocholine) is an endogenous intermediate which is formed in the rate-limiting step during the synthesis of phosphatydilcholine (21) and exogenously-administered CDP-choline is referred to as citicoline (39). Involvement of cell membrane phospholipids in traumatic or ischemic cerebral pathologies and in the pathophysiology of the cerebral edema is well known (7). Therefore, possible neuroprotective effects of citicoline, a membrane phosphatide precursor, has been studied in several previous reports $(3,4)$.

Although favorable effects of citicoline and its metabolites on ischemic/traumatic nervous system diseases were reported in several studies, only few studies, mainly conducted by our group, investigated citicoline's effect on peripheral nerve damage. In a previous study performed in our laboratory (31) topical citicoline was shown to decrease perineural scar tissue and to increase axonal regeneration as well as functional recovery in rats undergoing primary repair following peripheral nerve damage. In a follow-up study, we examined the effects of topically-administered citicoline, cytidine, choline, and cytidine plus choline in a primary anastomosis model of the sciatic nerve and found that cytidine plus choline and citicoline were efficient in preventing scar tissue formation and that cytidine plus choline increased the functional recovery by potentiating axonal regeneration (6). We also evaluated the effects of systemic administration of citicoline, cytidine, choline and cytidine plus choline on perineural scar tissue formation, axonal regeneration and functional recovery in the same model and observed that systemic administration of citicoline was beneficial in peripheral nerve incision followed by primary repair model by preventing scar tissue formation, increasing functional recovery and stimulating nerve regeneration (9).

In this study, we tested the dose dependency of citicoline administration on sciatic nerve recovery in a rat model of incision and primary anastomosis.

\section{MATERIAL and METHODS}

This study was performed in Uludag University, Faculty of Medicine, Laboratory Animals Breeding and Research Center between January 2011 and August 2011. The rats were supplied by Uludag University, Faculty of Medicine Laboratory Animals Breeding and Research Center, following the approval of Uludag University Laboratory Animals Care and Use Committee (2010-01/06).

A total of 60 female Wistar Albino rats weighing 200-270 g were anesthetized by intramuscular Ketamine $(70 \mathrm{mg} / \mathrm{kg}$; Ketalar, Eczacibasi, Turkey) and Xylazine (10 mg/kg; Rompun, Bayer, Turkey). Under prone position, extremities of rats were fixed on the operation table and operation area was elevated by placing a $1 \mathrm{~cm}$-thick roll of gauze bandage and cleaned using lodine (Glividon ${ }^{\circledR}$, Bikar llac San, Istanbul) solution. Surgical intervention was performed by the help of a surgical microscope (Zeiss Opmi 6, Carl Zeiss Meditec Inc., USA). Four,
1, 2, and 1 rat in Control, C-300, C-600 and C-900 groups died due to anesthesia problems.

A posterior longitudinal skin incision of $3 \mathrm{~cm}$ was made from right gluteal region through posterior femoral region. Fascia that surrounds the junction line of $\mathrm{m}$. gluteus superficialis and $\mathrm{m}$. biceps femoris, and its surface was opened with blunt dissection and sciatic nerve was exposed. Sciatic nerve was isolated from the surrounding tissues by dissecting the superficial membranous structures on the unifascicular area from sciatic foramen to the point at which tibial and peroneal branches were separated. A regular full-fold nerve incision was performed using micro scissors by slightly elevating sciatic nerve from sciatic foramen at a distance of $10 \mathrm{~mm}$ with root hook. Using epineural nerve repair technique, proximal and distal rudimentary nerves were sutured from two different points separated with an angle of $180^{\circ}$ using 8-0 polypropylene suture (Prolene, Ethicon ${ }^{\circledR} \mathrm{Ltd}$, Somerville NJ, USA) and primary anatomosis was created. The skin was then suture-closed by using 4-0 polypropylene (Prolene, Ethicon ${ }^{\circledR}$ Ltd, Somerville NJ, USA) suture.

Rats were then randomized to four groups: Control group received intraperitoneally (i.p.) $2 \mathrm{ml}$ saline $(0.9 \% \mathrm{NaCl})$ while rats in C-300, C-600 and C-900 groups received i.p. $300 \mathrm{mmol} /$ $\mathrm{kg}, 600 \mathrm{mmol} / \mathrm{kg}$ and $900 \mathrm{mmol} / \mathrm{kg}$ citicoline dissolved in $2 \mathrm{ml}$ saline immediately after the nerve injury and its repair, respectively. All rats recovered spontaneously from anesthesia; they were housed in groups of 4 in each cage after surgical intervention for mobilization and given free access to food and water ad libitum.

A total of 14 rats showed neuropathic pain-related injuries and amputation in the 3-4th and 5th toes of their right foot during the first 4-week period. These rats were not subjected to walking corridor test due to the fact that losses of toes would influence this test (Figure 1A).

\section{Functional Evaluation}

Walking corridor tests were performed for functional evaluation at $4^{\text {th }}, 8^{\text {th }}$ and $12^{\text {th }}$ weeks after the surgical intervention by immersing posterior feet of rats in ink and allowing rats to walk along a walking corridor constructed with $144 \times 10 \times 10 \mathrm{~cm}$ dimensions. Walking procedure was repeated for several times until the best print length and interdigital distances were observed. Results were recorded using the formula of Sciatic Function Index (SFI) for functional evaluation $(17,28)$ (Figure 1B).

\section{Electrophysiological Evaluation}

Electromyography (EMG) recordings were obtained using Dantec Keypoint 4 (Natus Medical Inc., San Carlos, CA, USA) device. Rats were anesthetized using intramuscular Ketamine (70 mg/kg; Ketalar, Eczacibasi, Turkey) and Xylazine (10 $\mathrm{mg} / \mathrm{kg}$; Rompun, Bayer, Turkey). Under prone position, all extremities of rats were fixed using plaster to the EMG table. The recordings were obtained from $\mathrm{m}$. gastrocnemius. Active recorder cup electrode was placed on the ventricle of the $m$. 
Gastrocnemius, reference cup electrode was placed on the dorsum of the foot and ground cup electrode electrode was placed on the abdomen. A monopolar needle electrode was inserted through a hole with a diameter of approximately 1-2 mm which was created with Ophtalmic Knife (MANI) on the skin of gluteal region. Needle electrode was positioned in the closest point to sciatic nerve. Stimulations were given at gradually increasing intensity with the durations of 0.04 ms. Best response in the EMG was recorded at the position in which, clinically, the best plantar flexion was observed. Attention was paid to allow a electronegative response to start from isoelectric line and to have few artifacts. Amplitude, area and latency of the composite muscular action potential formed was recorded (Figure 1C).

\section{Macroscopic Evaluation}

All rats were monitored for self-harming behaviors following the surgical procedure. Hyperemia, edema and ulceration were observed on right toes. For macroscopic evaluation of nerve injury, rats were sacrificed by high-dose Thiopental at end of post-operative $12^{\text {th }}$ week. The skin incision was opened and macroscopic evaluations of the closure of the cutaneous and muscular fascia, the adhesion of the nerve to the surrounding muscular mass and the separability of the nerve from these structures were transformed to quantitative scores by using a previously-described numerical grading scale (33) (Table I). Sciatic nerves were then excised en-bloc, with the tissue surrounding the introduction and the segment that was repaired, and they were placed in 4\% Glutaraldehyde for histopathological examination.

\section{Histomorphological Evaluation}

Tissues of approximately $0.5 \mathrm{~cm}$ in size, containing the area of anastomosis, were fixed overnight in $0.1 \mathrm{~mol} / \mathrm{L}$ phosphate buffer containing $4 \%$ glutharaldehyde ( $\mathrm{pH} 7.4)$. Next day, the tissue samples were post-fixed with $0.1 \mathrm{~mol} / \mathrm{L}$ phosphate buffer containing 1\% Osmium tetroxide (OsO4) for $2 \mathrm{~h}$ prior to dehydration in alcohol series with gradually increasing percentages, and were then treated with propylene oxide prior to polymerization at $70^{\circ} \mathrm{C}$ overnight by embedding in Spur's resin (Agar Scientific, Stansted, UK). Semi-fine sections at $0.5 \mu \mathrm{m}$ thickness were obtained from the resin blocks, perpendicular to long axis and were stained using a mixture of $1 \%$ toludine blue- $1 \%$ borax.

Axons were counted by a blinded investigator. Image capture and analysis were performed using a numeric camera (Sony Cybershot DSC-F717) attached to a light microscope (Nikon 4S-2 Alphaphot) and a computer with "Scion-Image" software. Image analyzing system was calibrated using a "table micrometer" before each measurement and counting. After the calculation of the total area of sciatic nerve sectional surface on the images acquired with $4 \mathrm{x}$ magnification, for each nerve sample, 10 microscope areas were captured with 40x objective, a "counting frame" was superimposed on the images captured. Myelinated axons that remained within the counting area were counted according to nonbiased counting terms and thereby, the number of axons per millimeter square (axonal density) was determined. Total number of myelinated axons was calculated using the surface area of sciatic nerve. Axonal density and total number

Table I: Numerical Grading Scale for Macroscopic Evaluation

\begin{tabular}{|l|c|l|}
\hline Tissue & Grade & Description \\
\hline Cutaneous and muscular fascia & 1 & Completely closed \\
& 2 & Partially open \\
Nerve adhesion and separability & 3 & Completely open \\
& 1 & No dissection or mild blunt dissection \\
\hline
\end{tabular}

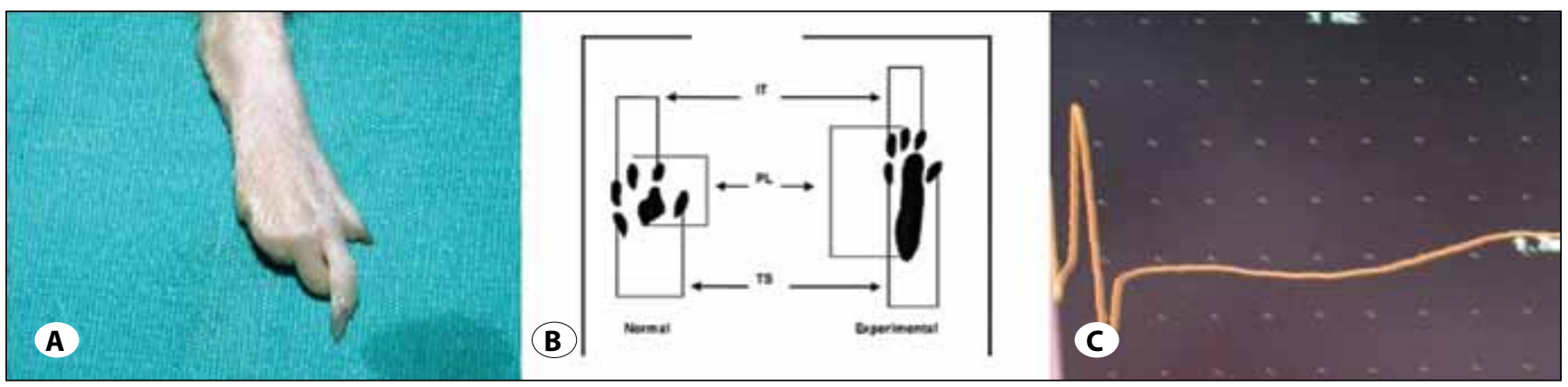

Figure 1: Amputation of $3^{\text {rd }}, 4^{\text {th }}$ and $5^{\text {th }}$ toes due to self-mutilation (A), representative image of footprint parameters used for calculation of Sciatic Function Index (B), an example of EMG recording (C). PL, compression length; TS, distance between $1^{\text {st }}$ and $5^{\text {th }}$ toes; IT, Distance between $2^{\text {nd }}$ and $4^{\text {th }}$ toes. 
of axons were compared with the counting values obtained from the Control group.

Seven nerves from each group were also prepared for analysis of perineural scar tissue formation. Sciatic nerves that were included the area of anastomosis were immersed in $0.2 \mathrm{M}$ phosphate buffered $4 \%$ paraformaldehyde fixative and then emmedded in paraffin. Seven $\mu$ m-thick longitudinal sections were cut by sliding microtome and stained with Masson's trichrome procedure. Thickness of the scar formation observed as a longidudinal connective tissue band (dark green color) was measured by a softare (Scion Image, ver. 4.02) from high resolution digital images. The scar tissue formation index was obtained by dividing the mean value of the thickness of the scar tissue by the mean value of the thickness of the nerve tissue as described previously (32).

\section{Statistical Analysis}

Statistical analyses were performed using SPSS 13.0 (Chicago, IL) software. Macroscopic, epineural scar tissue, functional and electrophysiological evaluation scores, axonal density and number measurements obtained with different doses of citicoline and from control group were evaluated using Kruskal-Wallis test and the significant groups were analyzed using Mann-Whitney- $U$ test. All quantitative results were expressed as arithmetic mean and $p<0.05$ was considered as significant in the statistical analysis.

\section{RESULTS}

\section{Functional Evaluation}

Citicoline treatment caused a significant improvement in Sciatic Function Index (SFI), calculated from walking corridor analyses, at 600 and $900 \mathrm{mmol} / \mathrm{kg}$ doses at 12 weeks and, 8 and 12 weeks, respectively (Figure 2). The improvement in SFI in C-900 group was also statistically significant compared to $C-300$ groups and $C-600$ groups at 8 weeks $(p<0.05)$ but no significant difference was observed between C-600 and C-900 groups at 12 weeks (Figure 2).

\section{Electrophysiological Evaluation}

Electrophysiological evaluation revealed that rats in C-600 and C-900 groups showed significantly $(p<0.05)$ lower latency at 12 weeks reflecting improved EMG recordings compared to those in the Control group. No significant difference was observed with regard to amplitude values of the nerve action potentials between C-300, C-600 and C-900 groups (Figure 3).

\section{Macroscopic Evaluation}

Macroscopic evaluation was performed 12 weeks after the surgery by re-opening the incisional line. We observed that cutaneous and muscular fasciae were completely closed without any sign of infection or inflammatory on the incisional line. Thick connective tissue was evident in rats in the Control group (Figure 4A) while fine membraneous tissue developed in rats in citicoline groups (Figure $4 \mathrm{~B}$ ). Using the previouslydescribed numerical evaluation scale (Table I) $(9,33)$, we found that citicoline treatment improved nerve adherence and separability score and that the improvement was statistically significant in C-300, C-600 and C-900 groups compared to Control group $(p<0.05, p<0.05$ and $p<0.001$, respectively) (Figure 4C). On the other hand, no significant difference was found between citicoline-treated groups (Figure 4C).

\section{Histomorphological Evaluation}

Mean axonal density was significantly greater in C-900 group compared to other groups $(p<0.001)$ (Figures 5A, 6A-D). Analyses of total number of myelinated axons also revealed

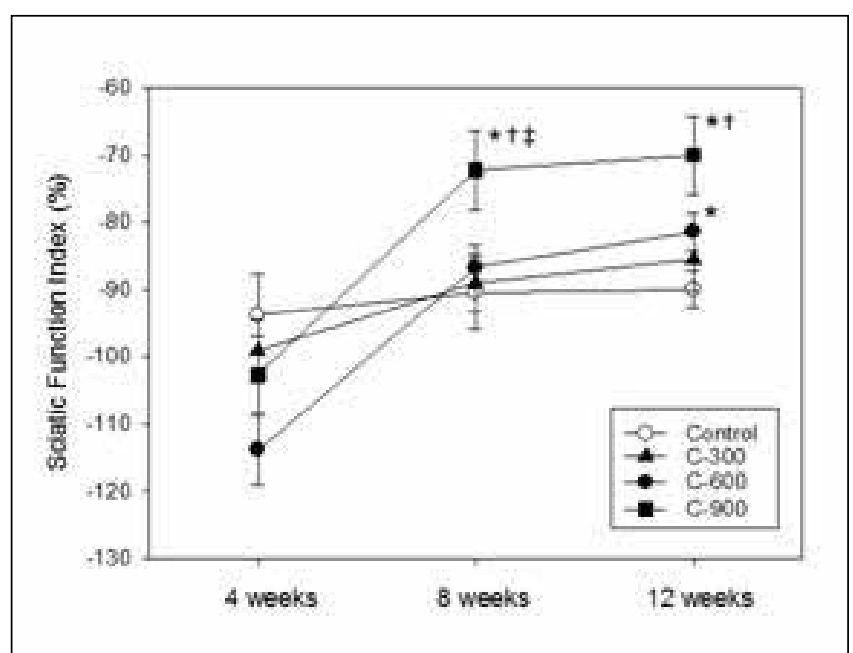

Figure 2: Sciatic function index (SFI) score at 4, 8, and 12 weeks after surgical repair of transected sciatic nerve in rats treated intraperitoneally with different doses of citicoline. ${ }^{*} \mathrm{p}<0.05$, $\dagger p<0.05$ and $\neq p<0.05$ compared to Control, C-300 and C-600 groups, respectively. C-300, C-600 and C-900 represent groups of rats that received intraperitoneal citicoline at doses 300,600 and $900 \mathrm{mmol} / \mathrm{kg}$, respectively.

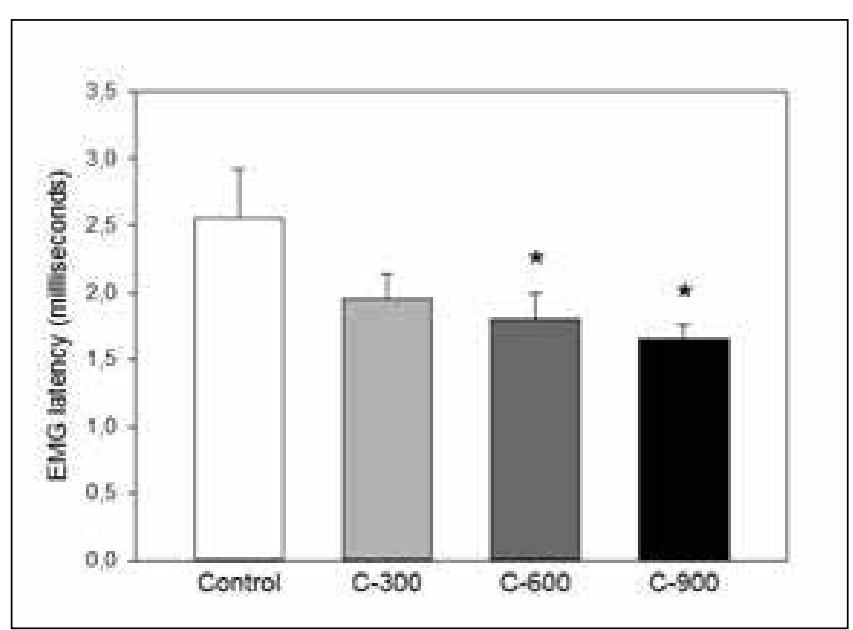

Figure 3: EMG latency at 12 weeks after surgical repair of transected sciatic nerve in rats treated intraperitoneally with different doses of citicoline. ${ }^{*} p<0.05$ compared to Control group. C-300, C-600 and C-900 represent groups of rats that received intraperitoneal citicoline at doses 300, 600 and $900 \mathrm{mmol} / \mathrm{kg}$, respectively. 


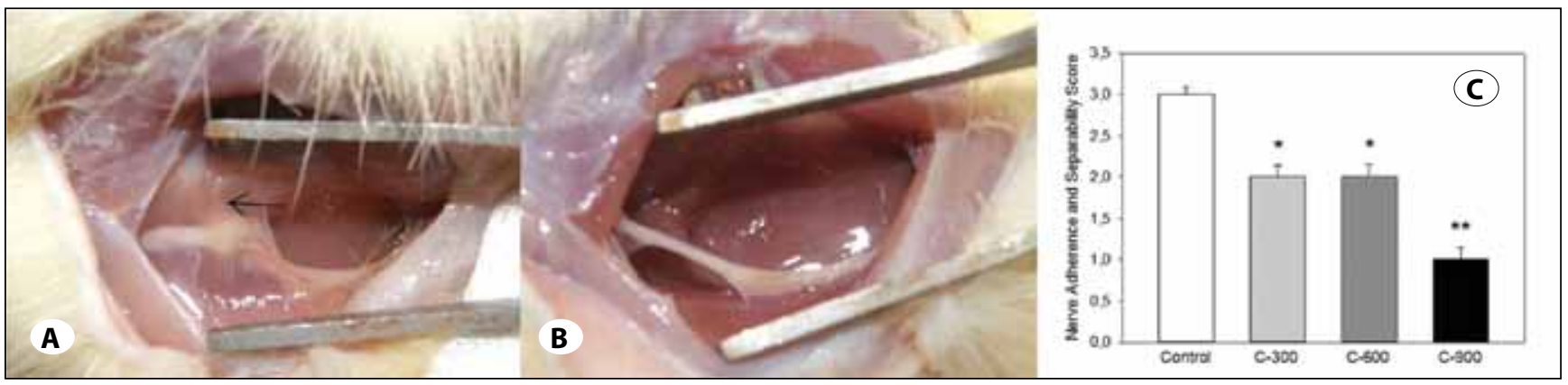

Figure 4: Representative images of thick connective tissue (black arrow) in rats in Control group (A) and fine membranous tissue in rats treated with $900 \mathrm{mmol} / \mathrm{kg}$ citicoline (B) that developed in the surgical field ( $x 4$ magnification), and graph depicting nerve adherence and separability score (C). ${ }^{*} \mathrm{p}<0.05$ and ${ }^{*} \mathrm{p}<0.001$ compared to Control group. C-300, C-600 and C-900 represent groups of rats that received intraperitoneal citicoline at doses 300,600 and $900 \mathrm{mmol} / \mathrm{kg}$, respectively.
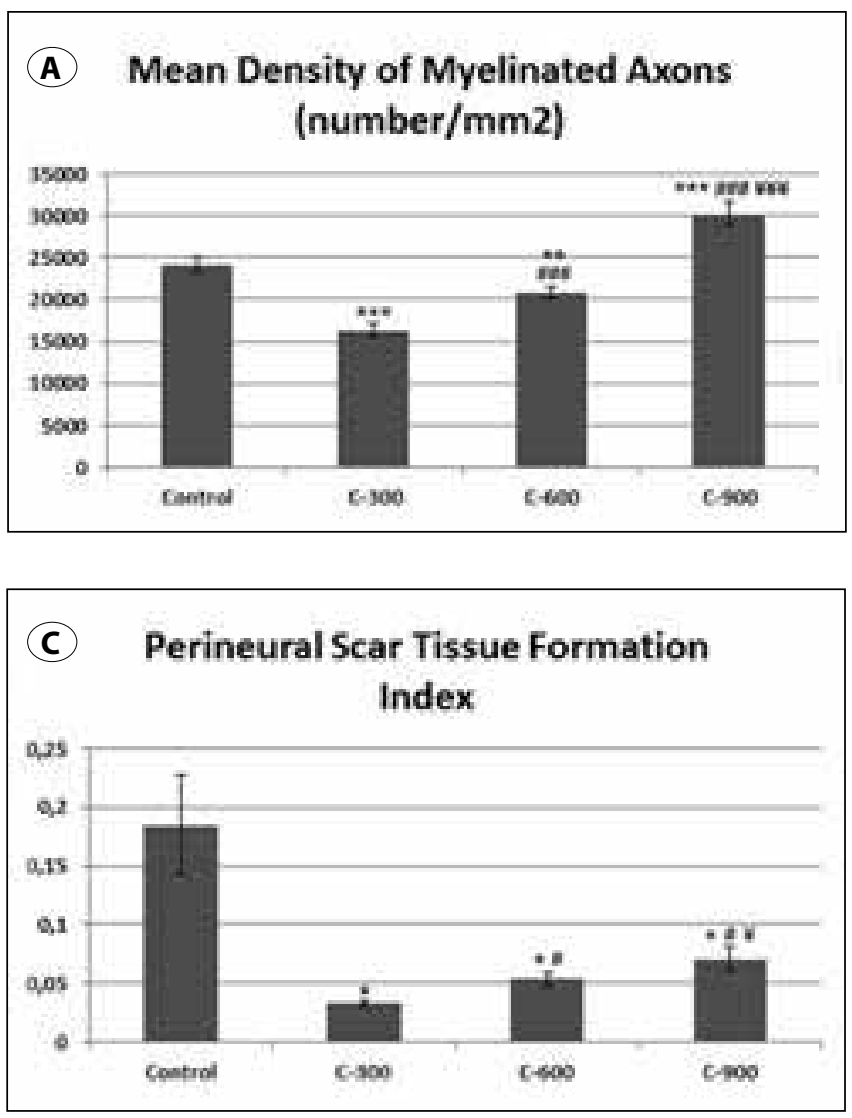

significantly $(p<0.001)$ greater number of myelinated axons in C-900 group compared to Control, C-300 and C-600 groups (Figures 5B, 6A-D). Masson's trichrome stainings and perineural scar tissue formation index showed lesser scar formation in the $C-300, C-600$ and $C-900$ groups compared to Control group $(p<0.05)$ (Figures $5 C, 7 A, B)$.

\section{DISCUSSION}

Several factors are involved in an ideal nerve repair including number of neurons that survived after the nerve injury, characteristics of axonal growth, status of the regenerated

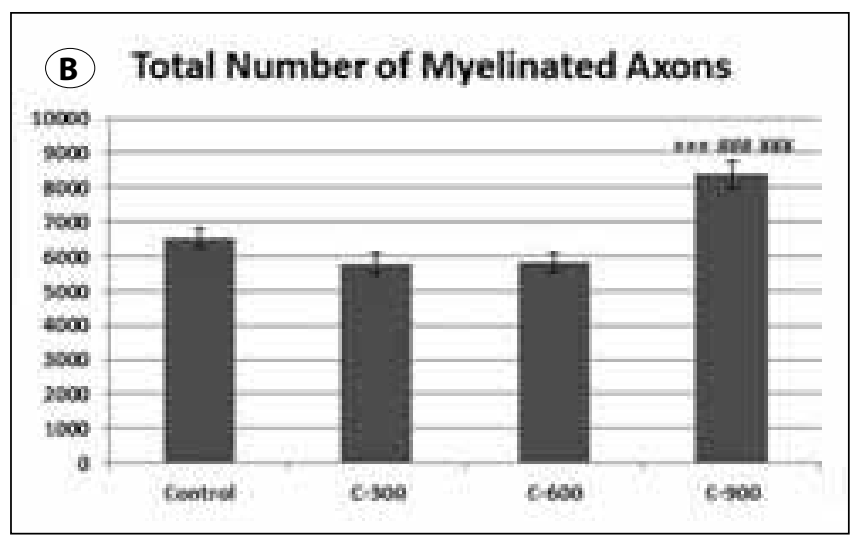

Figure 5: Graphs depicting mean density (A) and total number (B) of myelinated axons, and perineural scar tissue formation index

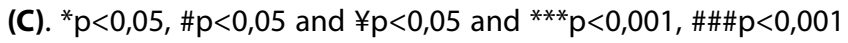
and $¥ ¥ ¥ p<0,001$ compared to Control, C-300 and C-600 groups, respectively. C-300, C-600 and C-900 represent groups of rats that received intraperitoneal citicoline at doses 300, 600 and 900 $\mathrm{mmol} / \mathrm{kg}$, respectively.

axon and status of the target tissue (16). Repair of axonal injury is a process that includes all the neuron. Axonal regeneration that results with axonal sprouting, growth and reinnervation, is the most important part of this process (24). Mechanisms such as the expression of growth factors, the activation of the transcription factors, cytokines, neuropeptides and inflammatory response account for an ideal regeneration (25). The procedure for studying peripheral nerve injury and repair includes anatomically rejoining the axon and putting a primary suture by a microsurgical technique and is still considered as the gold standard today (24). 


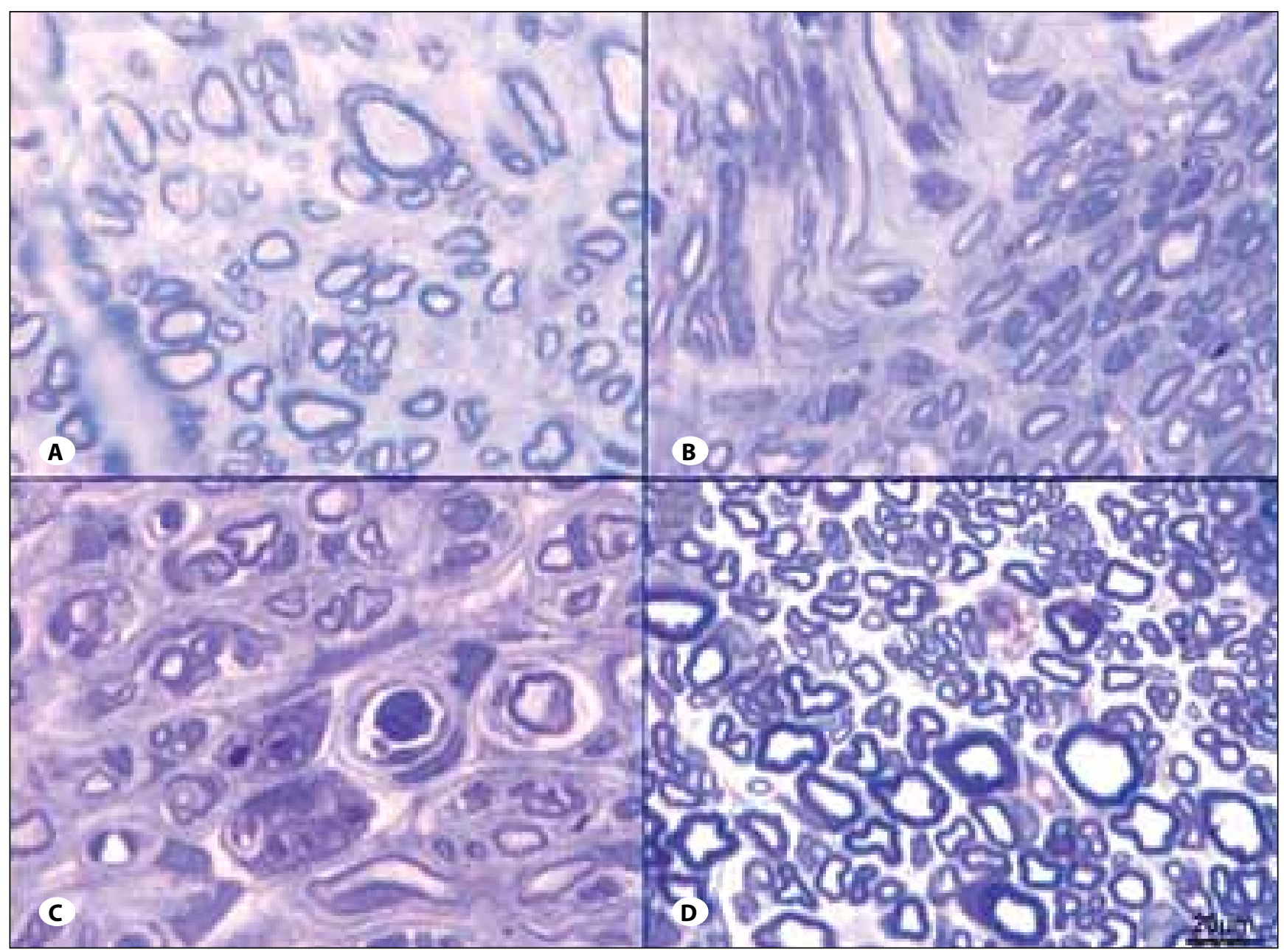

Figure 6: Demonstrative toludine blue stained images showing myelinated axon differences in Control, C-300, C-600 and C-900 groups (panels A, B, C and D, respectively). Scale bar, $20 \mu \mathrm{m}$.
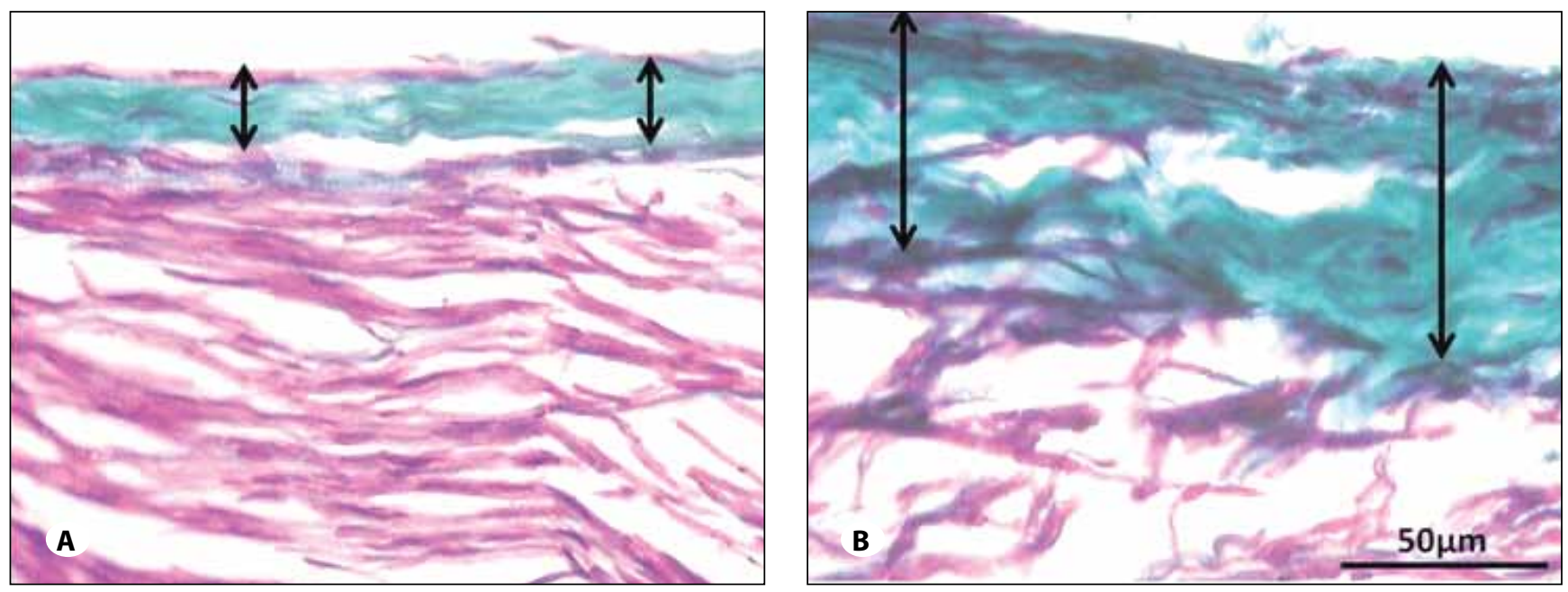

Figure 7: Demonstrative Masson's trichrome stained images showing scar formation which can be seen as a longidudinal connective tissue band in C-900 group and Control group (panels A and B, respectively). Scale bar, $50 \mu \mathrm{m}$. 
Citicoline is the drug form of CDP-choline, a metabolic intermediate in membrane phospholipid biosynthesis (21). Citicoline administration was shown to exhibit cardiovascular $(12,34)$ and neuroendocrine $(10,11,18,19)$ effects, and provide benefit in endotoxemia $(20,40)$ in experimental studies. Citicoline has been suggested to reduce brain injury in both experimental and clinical studies (2). In a previous study from our laboratory, we reported that topically-administered citicoline after primary saturation following peripheral nerve incision significantly increased axonal regeneration by preventing scar tissue formation (31). We determined, in a follow-up study (6) that was designed to investigate the effects of topically-administered citicoline, as well as its metabolites cytidine, choline, and cytidine plus choline following sciatic nerve incision and primary anastomosis that cytidine plus choline was as efficient as citicoline in reducing scar tissue formation and increasing functional recovery by potentiating axonal regeneration. In addition, a more recent study performed in our laboratory (9) demonstrated markedly reduced scar formation after systemic administration of citicoline. Therefore, the present study aimed to demonstrate the dose dependence of systemically-administered citicoline in a rat model of sciatic nerve incision and primary suture.

Our data showed that citicoline treatment reduced sciatic nerve injury in a dose-dependent manner in a rat model of peripheral nerve incision and primary anastomosis. Intraperitoneal citicoline treatment at $900 \mathrm{mmol} / \mathrm{kg}$ dose significantly improved sciatic function index, reduced EMG latency, perineural scar tissue formation as well as nerve adhesion and separability score, and enhanced mean density and total number of myelinated axons. At lower doses (i.e., 300 and $600 \mathrm{mmol} / \mathrm{kg}$ doses) citicoline was beneficial in terms of restoring sciatic nerve function while no improvement was observed with regard to mean density and total number of myelinated axons. Therefore, citicoline's beneficial effects on ameliorating sciatic nerve injury are dose-dependent.

Functional recovery after nerve injury has been reported in studies using autologous bypass techniques (35), nerve grafts that include Schwann cells (8), several endogenous and exogenous growth factors $(13,27,37,38)$, tubular systems that contain several substances in the nerve space (23) and fibrin glue (26). Today, few of these experimental studies could be implemented with successful outcomes. In good accord with previous observations $(6,9)$, our present results showed that citicoline treatment caused a significant improvement in Sciatic Function Index; the effect was more robust $900 \mathrm{mmol} /$ $\mathrm{kg}$ compared to $600 \mathrm{mmol} / \mathrm{kg}$ dose, but $300 \mathrm{mmol} / \mathrm{kg}$ dose was not efficient.

Amplitude value of the nerve action potential that might reflect functional recovery (22) depends on total electrical flow caused by myelinated axons (16). We therefore used the latency of the action potential obtained from $\mathrm{m}$. gastrocnemius records for evaluating functional recovery. We found that citicoline treatment significantly reduced latency at 600 and $900 \mathrm{mmol} / \mathrm{kg}$ doses, but $300 \mathrm{mmol} / \mathrm{kg}$ dose was ineffective. These data confirm our previous observations $(6,9)$, and further suggest that citicoline has a dose-dependent effect on functional and electrophysiological recovery in a rat model of sciatic nerve incision and primary repair.

Epineural scar tissue formation is also an important factor involved in functional loss and the recovery is suggested to be associated with the regeneration of Schwann cells that occurred with scar formation (29). It was demonstrated previously that structural alterations, such as increase of collagen and constriction of the endoneurial tubes, that begin at distal nerve segment after the incision caused a decrease in the fiber diameter by $80-90 \%$ by also proceeding to the denervation process (36). To date many strategies have been suggested to prevent scar formation (30) but none of them demonstrated the effectiveness of a single injection of an endogenous metabolite. Confirming previous reports $(6,9)$, our present data show that single intraperitoneal injection of citicoline reduces scar formation as indicated by the macroscopic nerve adherence and separability score and the microscopic perineural scar tissue formation index. We also found that these actions of citicoline appear even at the smallest dose $(300 \mathrm{mmol} / \mathrm{kg})$ used in the present study and that the highest dose $(900 \mathrm{mmol} / \mathrm{kg})$ produced significantly greater effect. In good accord with the data on functional and electrophysiological recovery, the present results on scar tissue suggest that citicoline administration dosedependently reduces scar formation.

The mechanism(s) by which citicoline improves functional recovery and reduces scar tissue formation remains largely unknown. Previous reports suggested that citicoline provided neuroprotection by reducing apoptotic cell death in experimental models (Alvarez et al., 1999 [60]; Fiedorowicz et al., 2008). Given that axotomized neurons die through apoptosis and their characteristic morphological alterations promote DNA fragmentation (15), it could be hypothesized that both citicoline prevents neuronal death resulting from the apoptosis caused by axonetmesis and potentialized axonal regeneration.

Another protective mechanism of action for citicoline may include prevention of phospholipase A2 (PLA2) activation (1). It was demonstrated that PLA2 was highly expressed in Schwann cells within the first 5 hours and that PLA2 was incrementally expressed in Schwann cells and in immune cells in the distal segment for 10 days following the peripheral nerve damage coinciding with the period during which myelin destruction and phagocytosis peak (14). PLA2 hydrolyzes phosphotydilcholine leading to liberation of lipophosphotydilcholine and arachidonic acid that induces myelin destruction. Blockade of PLA2 in the peripheral nerve incision decreases the phagocytosis in the distal segment via the destruction of myelin and axon. Therefore, it might be suggested that citicoline increases axonal recovery by preventing the activation of PLA2, which triggers Wallerian degeneration in the peripheral nerve damage, and thereby, the destruction of axon and myelin, by increasing the level 
of phospholipids (5) and by preventing the inflammatory response and scar tissue formation.

In conclusion, our data show that citicoline treatment ameliorates sciatic nerve injury in a dose-dependent manner in a rat model of peripheral nerve incision and primary anastomosis. Intraperitoneal citicoline treatment at 900 $\mathrm{mmol} / \mathrm{kg}$ dose significantly improves sciatic function index, reduces EMG latency, perineural scar tissue formation as well as nerve adhesion and separability score, and enhances mean density and total number of myelinated axons. At lower doses (i.e., 300 and $600 \mathrm{mmol} / \mathrm{kg}$ doses) citicoline may prove beneficial in terms of restoring sciatic nerve function while no improvement was observed with regard to mean density and total number of myelinated axons. Therefore, citicoline's beneficial effects on ameliorating sciatic nerve injury are dose-dependent. Future studies are required to further reveal the mechanisms by which citicoline proves beneficial in peripheral nerve damage.

\section{REFERENCES}

1. Adibhatla RM, Hatcher JF: Citicoline decreases phospholipase A2 stimulation and hydroxyl radical generation in transient cerebral ischemia. J Neurol Res 73:308-315, 2003

2. Adibhatla RM, Hatcher JF: Cytidine 5'-diphosphocholine (CDP-choline) in stroke and other CNS disorders. Neurochem Res 30:15-23, 2005

3. Adibhatla RM, Hatcher JF, Dempsey RJ: Effects of citicoline on phospholipid and glutathione levels in transient cerebral ischemia. Stroke 32:2376-2381, 2001

4. Adibhatla RM, Hatcher JF, Dempsey RJ: Citicoline: Neuroprotective mechanisms in cerebral ischemia. J Neurochem 80:12-23, 2002

5. Agut J, Lopez IG, Ortiz JA, Wurtman RJ: Oral cytidine 5'-diphosphate choline administration to rats increases brain phospholipid levels. Ann NY Acad Sci 695:318-320, 1993

6. Arslan E, Kocaeli H, Bekar A, Tolunay S, Ulus IH: CDP-choline and its endogenous metabolites, cytidine and choline, promote the nevre regeneration and improve the functional recovery of injured rat sciatic nerves. Neurol Res 33:766-773, 2011

7. Bramlett HM, Dietrich WD: Pathophysiology of cerebral ischemia and brain trauma: Similarities and differences. J Cereb Blood Flow Metab 24:133-150, 2004

8. Brown RE, Detlev E, Lyons SF, Suchy $\mathrm{H}$ : The use of cultured schwann cells in nerve repair in rabbit hind-limb model. J Reconstr Microsurg 12:149-152, 1996

9. Caner B, Kafa Ml, Bekar A, Kurt MA, Karli N, Cansev M, Ulus $\mathrm{IH}$ : Intraperitoneal administration of CDP-choline or a combination of cytidine plus choline improves nerve regeneration and functional recovery in a rat model of sciatic nerve injury. Neurol Res 34:238-245, 2012
10. Cansev M, Ilcol YO, Yilmaz MS, Hamurtekin E, Ulus $\mathbf{I H}$ : Peripheral administration of CDP-choline, phosphocholine or choline increases plasma adrenaline and noradrenaline concentrations. Auton Autacoid Pharmacol 28:41-58, 2008

11. Cansev M, Ilcol YO, Yilmaz MS, Hamurtekin E, Ulus IH: Choline, CDP-choline or phosphocholine increases plasma glucagon in rats: involvement of the peripheral autonomic nervous system. Eur J Pharmacol 589:315-322, 2008

12. Cansev M, Yilmaz MS, Ilcol YO, Hamurtekin E, Ulus IH: Cardiovascular effects of CDP-choline and its metabolites: Involvement of peripheral autonomic nervous system. Eur J Pharmacol 577:129-142, 2007

13. Chai $\mathrm{H}$, Wu W, So KF, Prevette DM, Oppenheim RW: Long term effects of a single dose of brain-derived neurotropic factor on motorneuron survival following spinal root avulsion in the adult rat. Neurosci Lett 274:147-150, 1999

14. De S, Trigueros MA, Kalyvas A, David S: Phospholipase A2 plays important role in myelin breakdown and phagocytosis during wallerian degeneration. Mol Cell Neurosci 24:753-765, 2003

15. Fu SY, Gordon T:The cellular and molecular basis of peripheral nevre regeneration. Mol Neurobiol 14:67-116, 1997

16. Fuminori $\mathrm{K}$, John $\mathrm{CF}$, Warren $\mathrm{CB}$ : Sciatic function Index, nevre conduction tests, muscle contraction, and axon morphometry asindicators of regeneration. Plast Reconstr Surg 98:1264-1271, 1996

17. Hare GM, Evans PJ, Mackinnon SE, Best TJ, Bain JR, Szalai JP, Hunter DA: Walking track analysis: A long-term assessment of peripheral nerve recovery. Plast Reconstr Surg 89:251-258, 1992

18. Ilcol YO, Cansev M, Yilmaz MS, Hamurtekin E, Ulus IH: Intraperitoneal administration of CDP-choline and its cholinergic and pyrimidinergic metabolites induce hyperglycemia in rats: Involvement of the sympathoadrenal system. Arch Physiol Biochem 113:186-201, 2007

19. Ilcol YO, Cansev M, Yilmaz MS, Hamurtekin E, Ulus IH: Peripheral administration of CDP-choline and its cholinergic metabolites increases serum insulin: Muscarinic and nicotinic acetylcholine receptors are both involved in their actions. Neurosci Lett 431:71-76, 2008

20. Ilcol YO, Yilmaz Z, Cansev M, Ulus IH: Choline or CDP-choline alters serum lipid responses to endotoxin in dogs and rats: Involvement of the peripheral nicotinic acetylcholine receptors. Shock 32:286-294, 2009

21. Kennedy EP, Weiss SB: The function of cytidine coenzymes in the biosynthesis of phospholipides. J Biol Chem 222:193-214, 1956

22. Kim DH, Connolly SE, Zhao S, Beuerman RW, Voorhies RM, Kline DG: Comparison of macropore, semipermeable, and nonpermeable collagen conduits in nerve repair. J Reconstr Microsurg 9:415-420, 1993 
23. Labrador RO, Buti M, Navarro X: Influence of collagen and laminin gels concentration on nerve regeneration after resection and tube repair. Exp Neurol 149:243-252, 1998

24. Lundborg G: 25 th Anniversary Presentation. A 25Year perspective of peripheral nerve surgery: Evolving neuroscientific concepts and clinical significance. J Hand Surg 25A:391-414, 2000

25. Makwana M, Raivich G: Molecular mechanisms in successful peripheral regeneration. FEBS J 272:2628-2638, 2005

26. Martins RS, Siqueira MG, Da Silva CF, Plese JPP: Overall assessment of regeneration in peripheral nerve lesion repair using fibrin glue, suture, or a combination of the 2 techniques in a rat model. Which is the ideal choice? Surg Neurol 64: 10-16, 2005

27. Mohiuddin L, Delcroix D, Fernyhough P, Tomlinson R: Focally administered nerve growth factor supresses molecular regenerative responses of axotomized peripheral afferent in rats. Neuroscience 91:265-271, 1999

28. Monte-Raso VV, Barbieri CV, Mazzer N, Yamasita AC, Barbieri $\mathrm{G}$ : Is the Sciatic Functional Index always reliable and reproducible? J Neurosci Meth 170:255-261, 2008

29. Nachemson AK, Lundborg G, Myrhage R, Kank F: Nerve regeneration and pharmacological suppresion of the scar reaction at the suture site. Scand J Plast Reconstr Surg 19: 255-260, 1985

30. Ngeow WC: Scar less: A review of methods of scar reduction at sites of peripheral nerve repair. Oral Surg Oral Med Oral Pathol Oral Radiol Endod 109:357-366, 2010

31. Ozay R, Bekar A, Kocaeli H, Karli N, Filiz G, Ulus IH: Citicoline improves functional recovery, promotes nerve regeneration, and reduces postoperative scarring after peripheral nerve surgery in rats. Surg Neurol 68: 615-622, 2007
32. Ozgenel GY, Filiz G: Effects of human amniotic fluid on peripheral nevre scarring and regeneration in rats. J Neurosurg 98:371-377, 2003

33. Petersen J, Russell L, Andrus K, MacKinnon M, Silver J, Kliot $M$ : Reduction of extraneural scarring by ADCON-T/N after surgical intervention. Neurosurgery 38:976-984, 1996

34. Savci V, Goktalay G, Cansev M, Cavun S, Yilmaz MS, Ulus IH: Intravenously injected CDP-choline increases blood pressure and reverses hypotension in haemorrhagic shock: Effect is mediated by central cholinergic activation. Eur J Pharmacol 468:129-139, 2003

35. Shah MH, Kasabian AK, Karp NS, Kolker AR, Dublin BA, Zhang $\mathrm{L}$, Sakuma J: Axonal regeneration through an autogenous nerve bypass: An experimental study in the rat. Ann Plast Surg 38:408-415, 1997

36. Sunderland S, Bradley KC: Endoneurial tube shrinkage in the distal segment of a severed nerve. J Comp Neurol 93:41 1-420, 1950

37. Tanabe K, Bonilla I, Winkles JA, Strittmatter SM: Fibroblast growth factor-inducible-14 is induced in axotomized neurons and neurite outgrowth. J Neurosci 23:9675-9686, 2003

38. Tham S, Dowsing B, Finkelstein D, Donato R, Cheema SS, Bartlett PF, Morrison WA: Leukemia inhibitory factor enhances the regeneration of transected rat sciatic nerve and the function of reinnervated muscle. J Neurosci Res 47: 208-215, 1997

39. Weiss GB: Metabolism and actions of CDP-choline as an endogenous compound and administered exogenously as citicoline. Life Sci 56:637-660, 1995

40. Yilmaz Z, Ozarda Y, Cansev M, Eralp O, Kocaturk M, Ulus IH: Choline or CDP-choline attenuates coagulation abnormalities and prevents the development of acute disseminated intravascular coagulation in dogs during endotoxemia. Blood Coagul Fibrinolysis 21:339-348, 2010 